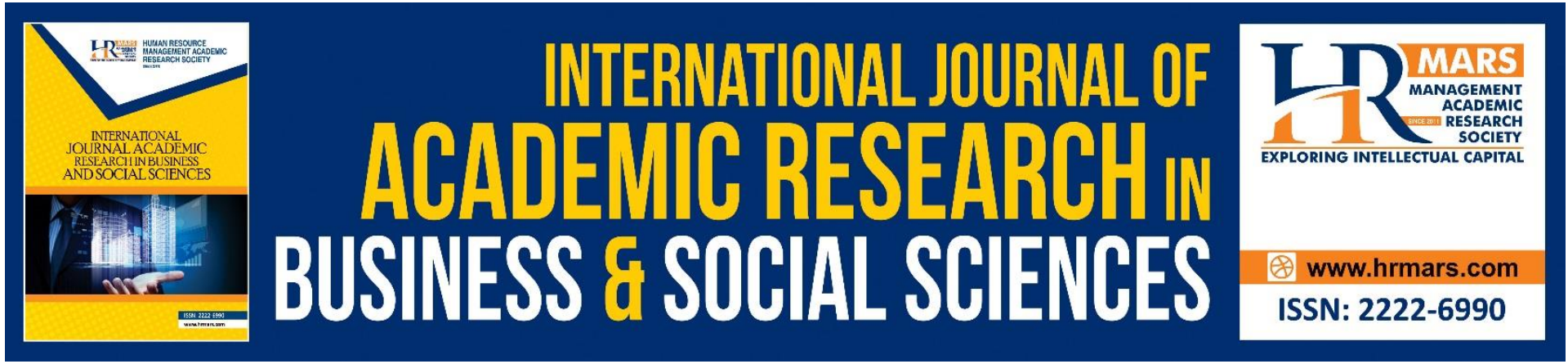

\title{
Arabic Syntactic Rules with Reference to Quranic Qurra
}

Mohamed Fathy Mohamed Abdelgelil, Hasan. A. F., Yusoh. F, El khayat. M. H. M., Razali. M. A., Hassan. A, Ab Aziz. N. S

To Link this Article: http://dx.doi.org/10.6007/IJARBSS/v11-i7/10463 DOI:10.6007/IJARBSS/v11-i7/10463

Received: 24 May 2021, Revised: 21 June 2021, Accepted: 10 July 2021

Published Online: 27 July 2021

In-Text Citation: (Abdelgelil et al., 2021)

To Cite this Article: Abdelgelil, M. F. M., Hasan. A. F., Yusoh. F, El khayat. M. H. M., Razali. M. A., Hassan. A, Ab Aziz. N. S. (2021). Arabic Syntactic Rules with Reference to Quranic Qurra. International Journal of Academic Research in Business and Social Sciences, 11(7), 1707-1711.

Copyright: (c) 2021 The Author(s)

Published by Human Resource Management Academic Research Society (www.hrmars.com)

This article is published under the Creative Commons Attribution (CC BY 4.0) license. Anyone may reproduce, distribute, translate and create derivative works of this article (for both commercial and non-commercial purposes), subject to full attribution to the original publication and authors. The full terms of this license may be seen at: http://creativecommons.org/licences/by/4.0/legalcode

Vol. 11, No. 7, 2021, Pg. 1707 - 1711

http://hrmars.com/index.php/pages/detail/IJARBSS

JOURNAL HOMEPAGE

Full Terms \& Conditions of access and use can be found at http://hrmars.com/index.php/pages/detail/publication-ethics 


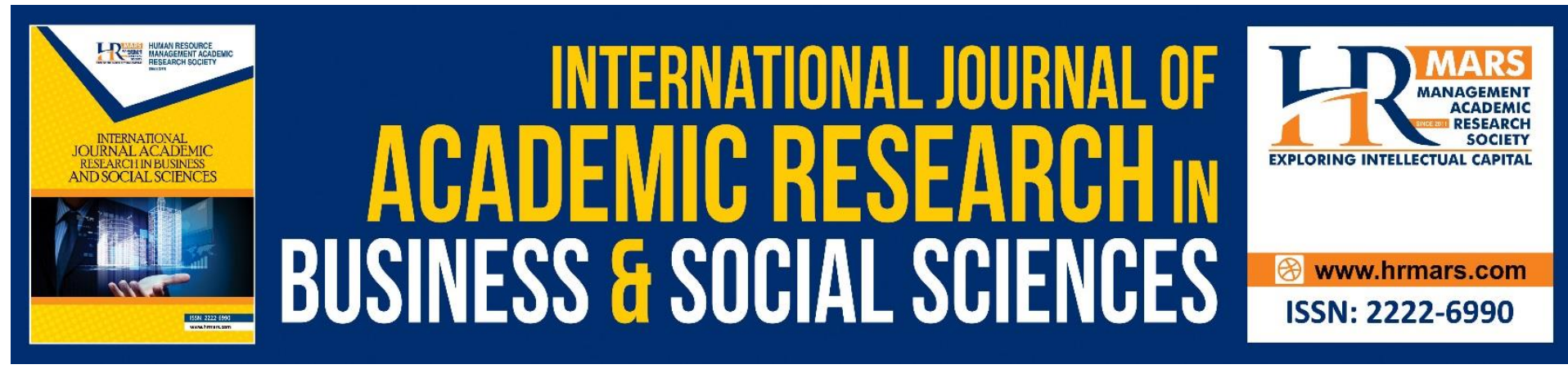

\title{
Arabic Syntactic Rules with Reference to Quranic Qurra
}

\author{
Mohamed Fathy Mohamed Abdelgelil, Hasan. A. F., Yusoh. F, \\ El khayat. M. H. M., Razali. M. A., Hassan. A, Ab Aziz. N. S \\ Faculty of Islamic Contemporary Studies (FKI), Sultan Zainal Abidin University (UniSZA), \\ 21300, Terengganu, MALAYSIA. \\ Email: mfathy@unisza.edu.my
}

\begin{abstract}
Syntax, morphology, linguistics and exegeses of the Quran are considered the basis for Tawjeeh Al-Qiraat (interpretation of the variations between Quranic Qira'at). However some grammatical rules were found contradicted with some Qira'at (modes of reading) and thus some syntacticians critiqued these Qira'at and questioned their authenticity. The purpose of this paper is to examine authenticity of these Qira'at on the one hand and the reasons why syntactician had critiqued these Qira'at. It also attempts to show which of the two schools of Arabic syntax were much critical to these Qira'at. The researcher followed an analytical approach by tracing the grammatical aspects in Qira'at which have been critiqued by syntacticians and the way in which such criticism has been dealt with by scholars of Qira'at. The study indicates that Qira'at must be followed as they were revealed no matter whether or not they correspond with Arabic spontaneous pronunciation and common syntactic rules. Scholars of Qira' at proved that all the Qira'at that were critiqued by syntacticians are robust; however, they do not correspond to the school of syntax these linguists advocate. Moreover, Basri scholars were much more critical of these Qira'at because they elaborated in citing these Qira'at paying little attention to their authenticity. Although these linguists were critical to these Qira'at, they cited them in great deal in their books.
\end{abstract}

Keywords: Qira'at, Grammatical rules, Syntacticians, Quraa, Grammaticality.

\section{Introduction}

Scholars of Quranic sciences have contributed widely to Tawjeeh Al-Qira'at (Abdelgelil, 2020) and they have refuted all the allegations against the Quran. There have been several allegations about Quranic Qira'at with regards to syntax, women and the language of the Quran. However, all such allegations were refuted by scholars and they proved that they were only flimsy augments (Abdelgelil, 2019; Abdelgelil, 2018).

\section{Untouchability of Quranic Qira'at}

It is no doubt that Qiraat are Sunnah-based tradition and hence they are untouchable i.e. they must be accepted whether or not they correspond with Arabic spontaneous pronunciation and Arabic syntactic rules. Scholars of Quranic sciences have established that 
the Quranic Qira'at that were criticized were linguistically robust; however, some Qira'at may not correspond to the school of syntax to which criticizers belong. As Al-Hafidh Abi Umar AlDani wonderfully put it "Imams of Qira'at (i.e. modes of readings) neither go by the most prominent Arabic Huruf (sounds) nor standardized syntactic rules but rather they take authenticity in terms of attribution, and narration. Once a narration is proved authentic (Abdelgelil, 2019; Abdelgelil, 2018), it can never be refuted by Arabic syntactic rules as Qira'at must be followed (Al-Dani, 2007, 2/ 860; Abdelgelil et al., 2020). Narrated by Al-Qurtubi that Imam Abi Nasr Abdul kareem Al-Qushairi said that "Qira' at are established as revelations to Prophet Mohammed and they were narrated by authentic narrators. Therefore, anyone who denies anything revealed in any of these Qira'at he denies the prophethood of Prophet Mohammed. As Arabic is taken from Prophet Mohammed and no one doubts his eloquence, there must be no contradiction between Qira'at and syntactic rules" (Al-Kurtubi, 2003, 5/ 4; Abdelgelil et al., 2021).

The grave mistake committed by some syntacticians was that they standardized grammatical rules by referring to Arabs without consulting the Quran. Thus, scholars of Quranic sciences wrote scholarly works to respond to the allegations of these syntacticians; these works were ultimately known as Tawjeeh Al-Qira'at.

There are two major schools of Arabic syntax namely Basri and Kufi schools. Looking at Basri school, we can find that they based their standardization of syntactic rules on two major sources namely, citing Imams of Qira'at and learning from eloquent Arabs i.e. prose and poetry written by eloquent Arabs. Basri school divided syntactic rules into two types; common constant rules and less common rules and they considered the common constant rules as a standard. The Kufi school was not far from these rules but they also elaborated on them by learning from the majority of Arab tribes as well as a larger number of Qira'at and thus Kufi schools draws from Quranic Qira'at more than the Basri School. This could be because not all Qira'at were available to Basri syntacticians. Furthermore, the fact that Kufi syntacticians did not criticize Qira' at as much Bara syntacticians did was because Kufa city was a famous place for Qira'at in which there were three popular Qurra namely, Asim, Hamzah and Al-Kisa'i. (Al-Tingari, 2009; Vol. 1, Pp. 95-116; Al-Ghrazi, 2015; Vol. 2, No. 6, Pp. 233-291).

Based on the aforementioned explanation, syntacticians mainly based standardizing rules on Arabic prose, poetry and the common Arab sayings. However, they were surprised by the fact that some Qira'at do not correspond with the rules they have standardized and hence they criticized these Qira'at. Certainly, this is a grave error since Qira'at have a similar status as verses and neither of them should be favored at the expense of the other. According to Ibn Al-Jazari, may Allah have mercy on him "All authentic narrations either verses or Qira'at attributed to Prophet Mohammed peace and blessings be upon him must be followed and all Muslims have no alternative but to believe in them as both Qira'at and verses are accurate revelations and each Qira'ah has the same status as a verse and thus all must be believed in and followed. It is not permissible to comply to one of them and leave the other assuming contradiction between the two. Have not you seen that Islamic Sharia is a unified whole in terms of Hudud, readings and commands of the Almighty Allah. There exists no contradiction between Qira'at i.e. if one Qira'ah endorsed one thing, the other does not abolish it. Although there exist some variations in terms of form between Qira'at, they endorse a similar ruling and thus if anyone adopted a particular Qira'ah, it does not mean that he does not want the others because anyone who disbelieve in one he disbelieves in the whole (Ibn Al-Jazari, 1/ 51). 


\section{Syntacticians' Incomplete Familiarity with All Rules}

Despite the good knowledge they had, syntacticians are not fully informed about all features of Arab linguistics so that they are not in a position to critique Qira'at. They are likely to have familiarity with some fields of linguistics but they must have missed some others. According to Umar Ibn Al-Khattab "poetry used to be Arab's most important science but when Islam came they turned their back to it due to more important issues such as Jihad and spreading Islam in Persia and Rome. When Islam had spread and Islamic state was stabilized, they came back to writing poetry but they did not refer to any earlier works in poetry. They documented some of these works but they lost many others. The offspring of Noman Ibn AlMundhir had a collection of poetry about him and his family, some of this collection was retained but many other poems were lost". It is also reported that Abu Amr Ibn Al-Ala said "what have reached to you from Arab's literary works is little since a great deal of works were done" (Al-Sayuti, 1998, 2/ 410). Imam Siuti narrated that Ibn Khalawaih said: "it is unanimously agreed that the language of the Quran is more eloquent than any other language of any work of literature" (Al-Sayuti, 1998, 1/ 168; Abdelgelil et al., 2018). Ibn Faris agreed to this when he said that "non but a prophet can entirely master Arabic." He also said "we have never heard that anyone from the past pretended to have mastered Arabic." He devoted one chapter which he entitled "Arabic has not reached us completely" and said that what we have received was only little. If we received everything that was written by Arabs, we would have a much greater bulks of poetry and prose and other forms of literature. We have seen linguists disagree over several issues regarding what was narrated by ancient Arabs. They hardly addressed the reality of such disagreement but they often preferred to base their arguments on probability and possibility" (Ibn Faris, 1997, P. 36). This indicates that scholars of Hadith have a deeper insight and that syntacticians are not fully familiar with Qira'at.

In fact, things are better understood when they are contrasted to their converse. Therefore, the critique made by syntacticians made scholars to conduct scholarly works that refute such allegations by providing explanations about the reasons for the variations of Qira'at. These endeavors ended up forming an independent branch of knowledge named Tawjeeh Al-Qiraat and thus that is the blessing of such a critique.

Before concluding, it is worth mentioning that Islamic scholars are much grateful to the contributions made by syntacticians. They (all Basri, Kufi and Andalusi) rendered great efforts to Islamic knowledge by standardizing Arabic syntactic rules and this has preserved Arabic and hence the Quran and Sunnah. Anyway, the above-mentioned critique were only made by a few syntacticians. According to Sybawaih "Qira'at are untouchable because they are sunnah-based." (Sibawih, 1988, 1/ 148) Even those syntacticians who critiqued some Qira'at, they did not deny Qira'at completely and they also cited these Qira'at in their works. It should be noted that we did not intend to belittle the status of these syntacticians or underestimate their great efforts for which we pray to Allah to reward them, but we aimed to show the significance of Tawjeeh Al-Qiraat.

\section{Conclusion}

The study revealed the following findings:

Qira'at are Sunnah-based and they must be followed whether or not they correspond to Arabic spontaneous pronunciation and the common syntactic rules or not. Scholars of Islam have established that all Qira'at that were critiqued are authentic but they do not correspond to the syntactic school to which syntactician belong. Basri syntacticians critiqued Qira' at much more than Kufi syntacticians because they cited them widely in their work without having to 
ascertain their authenticity. The syntacticians who critiqued some Qira'at did not entirely deny them but they critiqued Qira'at of some verses. They; however, had to cite and quote these Qira'at in their work.

\section{Acknowledgement}

Special thanks go to the Research Management, Innovation and Commercialization Centre (CREIM), Universiti Sultan Zainal Abidin.

\section{References}

Al-Quraan Al-Karim.

Abdelgelil, M. F. M. (2020). Grammarians' Critique of Qur'anic Qira'at. International Journal of Academic Research in Business and Social Sciences, 10(11), 1225-1231.

Abdelgelil, M. F. M. (2020). Solving the Quranic Issues with Quranic Qira'at, International Journal of Academic Research in Business and Social Sciences, 10(12), 36-42.

Abdelgelil, M. F. M., Al-Janayni, M. U., Baru, R., Hamzah, M. S., Razali, M. A. T. M., \& Ismail, F. Z. (2018). Tawjih Al-Qira'at Based on Inscription, Language, and Unusual Modes of Recitation According to Ibn Zanjalah. International Journal of Academic Research in Business and Social Sciences, 8(10), 362-370.

Abdelgelil, M. F. M., Daud, N. B., Omar, N. B., Ismail, F. Z. B., \& Wahab, A. H. B. A. (2018). Taujeeh Al-Qira'at Using Qur'an, Hadith and Poetry according to Ibn Zanjalah. International Journal of Academic Research in Business and Social Sciences, 8(10), 371-379.

Abdelgelil, M. F. M., Musolin, M. H., Serour, R. O. H., Abdullah, M. S., \& Noor, M. N. M. (2018). Law and Moral Values in the Holy Quran. International Journal of Academic Research in Business and Social Sciences, 8(11), 445-451.

Al-Dani, U. S. (2007). "Jam'e Albyan Fy Alqra'at Alsb'e". Alsharqh: Jam'eh Alsharqh.

Al-Ghrazi, F. M. (2015). "Ijaz Al-Qiraat Al-Quraniyyah". Sanaa: Al-Nasser University Journal, Vol. 2, No. 6, Pp. 233-291.

Al-Kurtubi, M. A. (2003). “Aljam'e Lahkam Alqran Walmbyn Lma Tdmnh Mn Alsnh Way Alfrqan". Alryad: Dar Alam Al-Kutub.

Al-Sayuti, A. A. (1998). "Almzhr Fy 'Elwm Allghh Wanwa'eha”. Byrwt: Dar Alktb Al'elmyh.

Al-Tingari, S. M. M. (2009). "Mwqf Alnhah Mn Alqra'at: Drash Tasylyh". Kuala Lumpur: UIAM, Vol. 1, Pp. 95-116.

Ibn Al-Jazari, M. M. M. (N. D). "Al-Nashr Fi Al-Qiraat Al-Ashr”. Cairo: Al-Matbaah Al-Tijariah Al-Kubra.

Ibn Faris, A. (1997). "Alsahiby Fy Figh Allghh Al'erbyah". Byrwt: Dar Alktb Al'elmyh.

Mohamed Fathy Mohamed Abdelgelil, Najihah Abd Wahid, Fauzi Bin Yusof, Anas Mohd Yunus, Ahmad Fauzi Hasan, The Administrative and Political Work of Women in the Light of the Verses of the Holy Quran, International Journal of Civil Engineering and Technology (IJCIET) 9(11), 2018, pp. 2732-2738.

Sibawih, A. U. (1988). "Al-Kitab". Cairo: Maktabah Al-Khanji. 